\title{
Elderly caregivers of other elderly living with and without children: burden, optimism and coping strategies
}

\author{
Idosos cuidadores de outros idosos que residem com e sem \\ crianças: sobrecarga, otimismo e estratégias de enfrentamento
}

Nathalia Alves de Oliveira (https://orcid.org/0000-0003-1665-8109) ${ }^{1}$
Érica Nestor Souza (https://orcid.org/0000-0002-7952-7643) ${ }^{1}$
Bruna Moretti Luchesi (https://orcid.org/0000-0002-0508-0818) ${ }^{2}$
Tiago da Silva Alexandre (https://orcid.org/0000-0003-3791-9793) ${ }^{3}$
Keika Inouye (http://orcid.org/0000-0003-3570-0704) ${ }^{3}$
Sofia Cristina Iost Pavarini (https://orcid.org/0000-0001-9359-8600) ${ }^{3}$
${ }^{1}$ Programa de PósGraduação em Enfermagem, Universidade Federal de São Carlos. Rodovia Washington Luis, Km 310. 13565-905 São Carlos SP Brasil. nathaliaalves.oliveira@ gmail.com

${ }^{2}$ Universidade Federal de Mato Grosso do Sul. Três Lagoas MS Brasil. ${ }^{3}$ Departamento de Gerontologia, Universidade Federal de São Carlos. São Carlos SP Brasil.

\begin{abstract}
This article aims to compare level of burden, optimism and coping strategies among elderly caregivers of other elderly individuals who reside with and without children. A cross-sectional study was with a sample of 301 elderly caregivers of elderly Brazilians seen in primary health care. Among the 301 caregivers interviewed, 44 resided with children and 257 did not. Evaluations involved the administration of the Zarit Burden Inventory, Spirituality Scale (optimism) and Coping Strategies Inventory. Either the Student's $t$-test or the Mann-Whitney U-test was used for the comparisons between the two groups. Burden level was significantly higher among elderly caregivers who resided with children $(p=0.01)$. No significant differences were found with regard to optimism. Elderly caregivers who did not reside with children reported significantly greater use of coping strategies focused on the expression of negative emotions $(p<0.01)$, religiosity $(p<$ 0.01 ) and the inhibition of negative emotions ( $p$ $=0.01$ ). The elderly caregivers of other elderly individuals who resided with children had a higher level of burden and used coping strategies less than those who did not reside with children.

Key words Child, Aged, Caregivers, Family relations
\end{abstract}

Resumo $O$ objetivo deste artigo é comparar o nivel de sobrecarga, otimismo e as estratégias de enfrentamento de idosos cuidadores de idosos que residem com e sem crianças. Estudo transversal realizado com amostra de 301 idosos cuidadores cadastrados nas Unidades de Saúde da Família. Foram entrevistados 301 idosos cuidadores, sendo que 257 não residiam com crianças e 44 residiam. Os instrumentos utilizados foram Escala de Sobrecarga de Zarit, Escala de Espiritualidade de Pinto e Pais Ribeiro e Inventário para Avaliação das Estratégias de Enfrentamento. Foram usados o teste T de Student e teste U Mann-Whitney para a comparação entre os dois grupos. O nivel de sobrecarga foi significativamente maior nos idosos cuidadores que residiam com crianças $(p=0,01) e$ não houve diferença significativa para o otimismo. Os idosos cuidadores que não residiam com crianças reportaram o uso significativamente superior de estratégias de enfrentamento focadas em emoções negativas $(p<0,01)$, religiosidade $(p<0,01)$ e inibição de emoções negativas $(p=0,01)$. O nível de sobrecarga foi maior entre os idosos cuidadores que residiam com crianças. Os idosos cuidadores que não tinham crianças no domicílio reportaram maior uso de estratégias focadas na emoção e na religião para enfrentar as demandas do cuidado ao idoso.

Palavras-chave Criança, Idoso, Cuidadores, Relações familiares 


\section{Introduction}

Studies addressing the implications and stress of informal care have increased with the growing number of elderly individuals who perform the role of caregiver for other elderly individuals and children in the family ${ }^{1,2}$. Caring for others with different degrees of dependence and from different generations can lead a caregiver to experience burdensome situations for which different coping strategies are needed. Studies involving grandparents who take care of their grandchildren demonstrate that childcare can exert a positive influence on intergenerational exchanges. However, it is important to maintain a balance between the grandparents' involvement in childcare and other activities, as an excessive number of tasks directed at caring for children is burdensome and can exert a negative influence on the health of grandparents $s^{3-5}$.

Among the population of caregivers for the elderly, burden is one of the aspects most associated with a negative impact. Excessive burden taxes the caregiver's capacities ${ }^{6}$ and can affect both physical and psychological health, leading to mood changes, depression, stress and a diminished quality of life as well as causing harm to familial and social relationships ${ }^{4-7}$.

The development of coping strategies is indicated to minimize the occurrence of the negative effects of an excessive care burden. Such strategies have a protective effect by reducing the demands that tax the caregiver ${ }^{8,9}$. Among caregivers of the elderly, the most often employed coping strategies of an emotional nature are focused on religion, resignation and the minimization of the negative effects of the problem ${ }^{10}$. Elderly caregivers tend to use more inherent forms of coping, such as distancing, resigning themselves to the situation or redefining their preference ${ }^{11}$.

The pursuit of better coping strategies is linked to one's context and psychological mechanisms ${ }^{12,13}$. The degree of optimism is a characteristic of the personality of each individual and an aspect that assists in seeking better results ${ }^{14,15}$. Recent investigations have shown that sufficient optimism results in more effective coping strategies, as individuals tend to act in a more proactive manner to deal directly with the source of the problem ${ }^{16,17}$. Among caregivers of dependent individuals, a higher degree of optimism is related to a lower level of care-related burden ${ }^{18}$. Moreover, studies involving elderly caregivers report that high degrees of optimism are related to healthier living habits, a lower occurrence of depressive symptoms and better coping in burdensome situations ${ }^{19,20}$.

With the increase in the longevity of the population and changes in family structure, elderly individuals have increasingly taken on the role of caregiver for more dependent elderly individuals as well as children. This requires different skills to meet the particularities of care for different generations. Although many studies have discussed the negative consequences of care-related burden and ways to minimize such burden, the literature on burden, coping strategies and optimism among elderly caregivers of elderly individuals with and without the presence of children remains scarce.

Considering the importance of evaluating these aspects in elderly caregivers who are exposed to different forms of care and the implications regarding the physical and psychological health of the caregiver as well as relationships between children and elderly individuals, the aim of the present study was to compare burden, coping strategies and optimism among elderly caregivers who reside with and without children.

\section{Material and Methods}

\section{Participants}

The present cross-sectional study is part of a larger investigation entitled "Variables associated with cognition in elderly caregivers" conducted at the Federal University of São Carlos with informal caregivers aged 60 years or older who took care of other elderly individuals identified at 18 primary care units in the city of São Carlos, state of São Paulo, southeastern Brazil. The following were the inclusion criteria: 1 ) age $\geq 60$ years; 2 ) registration with a primary care unit in the city of São Carlos, Brazil; 3) at-home caregiver of an individual aged $\geq 60$ years dependent with regard to at least one basic activity of daily living evaluated using the Katz Inde ${ }^{21}$ and/or one instrumental activity of daily living evaluated using the Lawton and Brody Scale ${ }^{22}$.

The teams at the primary care units provided a list of 594 families. The sample selection method is described in the study entitled "The evaluation of perceived stress and associated factors in elderly caregivers" by Luchesi et al. ${ }^{23}$. Following the selection process, 351 elderly caregivers were interviewed, 50 of whom were excluded for not providing sufficient information on coping strategies. Thus, the final sample was composed 
of 301 elderly caregivers of other elderly individuals in the home setting. The caregivers were separated into groups based on the presence/absence of children in the home. Group 1 was formed of caregivers who did not reside with children $(\mathrm{n}=$ 257) and Group 2 was composed of caregivers who resided with children $(\mathrm{n}=44)$.

\section{Data acquisition}

Interviews were held in the participants' homes in a single, individual session lasting approximately 1.5 hours and were conducted between April and November 2014. This study received approval from the Human Research Ethics Committee of the Federal University of São Carlos. All participants were informed about the objectives of the study, and before starting to collect data, the Informed Consent Form was presented and discussed with each participant. After clarification, a copy of the document was requested and a copy of the document was sent to the participants.

The following evaluations were performed:

Functional capacity: The Katz Index was used to evaluate independence on six basic activities of daily living and the participants were classified as either dependent (dependence for one or more functions) or independent (no difficulty with any of the activities evaluated $)^{21}$. The Lawton and Brody Scale was used to evaluate instrumental activities of daily living (score 7 to 21 points), with the following interpretation of the results: 21 points = independence; 8 to 20 points = partial dependence; and 7 points $=$ complete dependence ${ }^{22}$. This scale was used to classify both the caregivers and the elderly individuals who received care.

Socio-demographic characterization of caregiver and inter-generational cohabitation: sex, age (in years), schooling (in years), marital status (with/ without conjugal life), household income (categorized based on the Brazilian monthly minimum wage [BMMW]: 1 to 2 times the BMMW; 2 to 4 times the BMMW; > 4 times the BMMW; and no response), number of residents in the home (2 to $3 ; 4$ to $5 ; \geq 6$ ), who lives in the home (spouse; spouse and (step) sons/daughters; spouse, (step) sons/daughters and grandchildren; other arrangements), who receives care (degree of kinship between caregiver and person who receives care: parent; spouse; sibling; other), length of time in the role of caregiver (in years), duration of daily care (in hours), resides with child (yes/no), number of children in the home, child's sex, child's age (in years), degree of kinship to child (grandparent; great grandparent; parent; other), length of time living with child (in years), duration of daily cohabitation (in hours), whether interviewee cares for child (yes/no) and duration of daily care for child (in hours).

Burden related to caring for elderly individual: The Zarit Burden Inventory ${ }^{24}$ was used for this evaluation, which is composed of 22 items addressing the perceived impact of care giving on the physical health, emotional wellbeing, social activities and finances of the caregiver. The total score is determined by the sum of the item scores and ranges from 0 to 88 points, with higher scores denoting a greater degree of burden.

Optimism: The Spirituality Scale developed by Pinto and Pais-Ribeiro ${ }^{25,26}$ was used for this evaluation and is divided into two domains: Beliefs and Hope/Optimism. Only the three items of the Hope/Optimism domain were employed in the present study, which address the positive sense of life guided by hopeful prospects for the future $^{25}$. The final score corresponds to the mean of the item scores and ranges from 1 to 4 points, with a higher score denoting a greater degree of optimism.

Coping strategies: The Coping Strategies Inventory ${ }^{13-27}$ was used for this evaluation, which consists of 19 items scored on four levels of intensity. The items are grouped into five factors: Factor 1: expression of negative emotions (items 1, 7, 9, 13, 18 and 19) - behavioral excesses and risk behaviors that allow the individual to spare himself/ herself of feelings of guilt, resentment or doubts, deal with situations of anxiety and depression and make contact with others to achieve assistance or maintain emotional activation. Factor 2: environmental control (items 5, 10, 14 and 16) - attempts at the indirect control of the environment. This encompasses the belief that others will take care of an event and allowing others to deal with a problem, awaiting further information prior to acting and stopping activities when necessary to seek social support. These aspects constitute a proactive stance interceded by the acts of others to whom the individual is able to appeal. Factor 3: religiosity (items 8 and 15) - as a shock absorbing factor that regulates emotions. Factor 4: avoidance behavior (items 4, 6, 12 and 17) - based on minimizing stress. This factor is related to cognitive mechanisms that mitigate the stressful potential of an event and contribute toward diminishing anxiety and depression. Factor 5: inhibition of emotions (items 2, 3 and 11) - the individual tends to withdraw into his/her inner world without attempting to change it or reinterpret it. 
The results were analyzed based on the factors, with the determination of the frequency with which the caregivers use such strategies. The following scores were attributed to each factor: Factor $1-6$ to 24 points; Factor $2-4$ to 16 points; Factor $3-2$ to 8 points; Factor $4-4$ to 16 points; and Factor $5-3$ to 12 points.

\section{Data analysis}

The data were analyzed using the Stata $14^{\oplus}$ program for Windows ${ }^{\mathrm{TM}}$. The Shapiro-Wilk test was used to determine the distribution (normal or non-normal) of the data. The dependent variables burden, optimism and Factors 1, 2 and 3 of the Coping Strategies Inventory demonstrated non-normal distribution $(\mathrm{p}=0.00)$, whereas Factors $4(\mathrm{p}=0.97)$ and $5(\mathrm{p}=0.37)$ of the Coping Strategies Inventory demonstrated normal distribution. The independent variables age, schooling, income, length of time in the role of caregiver, daily duration of care giving activities, who lives in the home and degree of kinship to the individual receiving the care demonstrated non-normal distribution $(\mathrm{p}=0.00)$. The Mann-Whitney U-test was used to compare median values of Groups 1 and 2 with regard to nonparametric variables and the Student's t-test was used to compare the means of the parametric variables between groups. The chi-square test was used to compare the proportions of Groups 1 and 2. The level of significance for all statistical tests was set to $5 \%(\mathrm{p} \leq 0.05)$.

\section{Results}

Table 1 displays the socio-demographic and functional capacity characteristics of the elderly caregivers according to group (Group 1: 85.3\%, $\mathrm{n}=$ 257; Group 2:14.7\%; $\mathrm{n}=44)$. Age ranged from 60 to 95 years in Group 1 and 60 to 81 years in Group 2. Thus, the participants who resided with children were younger than those who did not reside with children $(\mathrm{p}=0.02)$.

Most caregivers offered care to their spouse (Group 1: 82.9\%; Group 2: 93.1\%). Most individuals who received care were male (Group 1: $66.9 \%$; Group 2: $77.3 \%$ ), with a median age of 73 years in Group 1 and 69 years in Group 2. With regard to basic activities of daily living, 68.5\% were independent and $31.5 \%$ were considered dependent in Group 1, whereas 68.2\% were independent and 31.8\% were considered dependent in Group 2. For instrumental activities of daily living, $85.2 \%$ were partially dependent and $14.8 \%$ were dependent in Group 1, whereas 90.9\% were partially dependent and $9.1 \%$ were dependent in Group 2.

To understand the context of the 44 elderly caregivers who resided with children (Group 2), information was collected on inter-generational cohabitation. Fifty-nine children lived with the elderly caregivers. A total of $77.3 \%$ of these caregivers resided with one child, $13.6 \%$ resided with two children, $6.8 \%$ resided with three children and $2.3 \%$ resided with four children. The majority of children $(52.6 \% ; \mathrm{n}=31)$ was male and $47.4 \%(\mathrm{n}=28)$ were female, with a mean age of $6.0 \pm 3.4$ years (range: zero to 12 years). Most of the children $(84.2 \% ; \mathrm{n}=50)$ were grandchildren of the caregivers, followed by great grandchildren $(9.0 \% ; n=5)$, children $(4.5 \% ; n=3)$ and others $(2.3 \% ; n=1)$. Mean duration of cohabitation between the child and elderly caregiver was $5.4 \pm$ 5.1 years, the mean duration of daily cohabitation was $8.4 \pm 5.1$ hours and the mean duration of daily care for the children was $6.3 \pm 5.1$ hours.

Table 2 displays the scores for burden, optimism and the factors that compose the Coping Strategies Inventory for the elderly caregivers in Groups 1 and 2.

The elderly caregivers who resided with children had a greater burden in comparison to those who did not reside with children $(\mathrm{p}=0.01)$. No significant differences between groups were found with regard to optimism. The caregivers who did not reside with children reported greater use of coping strategies categorized in Factor 1, which reflects the expression of negative emotions through risk behaviors that can compromise physical and psychological health $(\mathrm{p}<0.01)$, Factor 3, which regards religiosity $(\mathrm{p}<0.01)$, and Factor 5, which regards the inhibition of negative emotions $(p=0.01)$.

\section{Discussion}

The present study aimed to compare burden, coping strategies and optimism among elderly caregivers who reside with and without children. The elderly caregivers of other elderly individuals who resided with children were younger and had a higher level of burden. In contrast, the caregivers who did not reside with children reported greater use of coping strategies focused on religion. No differences were identified for optimism.

Considering studies that have employed the Zarit Burden Inventory, the scores in the two 
Table 1. Characteristics of elderly caregivers according to condition of residing with a child or not, São Carlos, SP, Brazil, 2014.

\begin{tabular}{|c|c|c|c|}
\hline Variable & $\begin{array}{l}\text { Resides without } \\
\text { child (Group 1) } \\
\text { n = 257 }\end{array}$ & $\begin{array}{c}\text { Resides with child } \\
\text { (Group 2) } \\
\mathrm{n}=44\end{array}$ & p-value \\
\hline Sex & & & $>0,05$ \\
\hline Female & $74.3 \%$ & $81.8 \%$ & \\
\hline Male & $25.7 \%$ & $18.2 \%$ & \\
\hline Age (years) & $69.0^{*}$ & $65.5^{* \dagger}$ & 0,02 \\
\hline Marital status & & & $>0,05$ \\
\hline With conjugal life & $88.7 \%$ & $95.5 \%$ & \\
\hline Without conjugal life & $11.3 \%$ & $4.5 \%$ & \\
\hline Schooling (years) & $3.0^{*}$ & $4.0^{*}$ & $>0,05$ \\
\hline \multicolumn{4}{|l|}{ Household income } \\
\hline 1 to 2 times BMMW & $37.7 \%$ & $22.7 \%$ & \\
\hline 2 to 4 times BMMW & $38.1 \%$ & $36.3 \%$ & \\
\hline$>4$ times BMMW & $17.5 \%$ & $29.5 \%$ & \\
\hline No response & $6.7 \%$ & $11.5 \%$ & \\
\hline Number of residents in home & & & $>0,05$ \\
\hline 2 to 3 & $79.0 \%$ & $18.2 \%$ & \\
\hline 4 to 5 & $19.5 \%$ & $54.5 \%$ & \\
\hline 6 or more & $1.5 \%$ & $27.3 \%$ & \\
\hline Resides with & & & $>0,05$ \\
\hline Spouse & $47.8 \%$ & - & \\
\hline Spouse, (step) sons/daughters & $25.3 \%$ & $2.3 \%$ & \\
\hline $\begin{array}{l}\text { Spouse, (step) sons/daughters, grandchildren, } \\
\text { great grandchildren }\end{array}$ & $3.5 \%$ & $38.6 \%$ & \\
\hline Other relatives & $8.2 \%$ & $2.3 \%$ & \\
\hline Other arrangements & $15.2 \%$ & $56.8 \%$ & \\
\hline Katz Index & & & $>0,05$ \\
\hline Independent & $87.9 \%$ & $81.8 \%$ & \\
\hline Dependent & $12.1 \%$ & $18.2 \%$ & \\
\hline Lawton Scale & & & $>0,05$ \\
\hline Independence & $41.6 \%$ & $38.6 \%$ & \\
\hline Partial dependence & $58.4 \%$ & $61.4 \%$ & \\
\hline Complete dependence & $0.0 \%$ & $0.0 \%$ & \\
\hline
\end{tabular}

BMMW: Brazilian monthly minimum wage; ${ }^{\star}$ data expressed as median; ${ }^{\dagger} \mathrm{p} \leq 0.05$.

groups of the present investigation were lower than those reported in a study conducted in Taiwan, in which the mean score was 25.1 points $^{28}$, and two Brazilian studies, in which scores of 27.8 points ${ }^{29}$ and 30.6 points $^{30}$ are reported. According to the researchers cited, burden is influenced by the particular characteristics of each sample. Thus, the differences in the score of the Zarit Inventory may be due to the different contexts experienced on the part of the caregivers. In a study conducted in Australia employing the Zarit Inventory to investigate the prevalence and predictors of burden among 732 caregivers of elderly individuals, moderate levels were found: 22.9 points at the onset of the study, 25.5 points after six months and 27.7 points after 12 months of care. The predictors of burden were behavioral symptoms of the elderly individual, such as the use of antipsychotics and antidepressants, as well as accentuated functional decline ${ }^{31}$.

The relationship between burden associated with the care of an elderly individual and the presence of children in the home is not clear in the literature. Indeed, studies addressing intergenerational aspects demonstrate that this relationship is marked by ambivalent characteristics. A study analyzing the effects of full-time care of grandchildren by grandparents found that the caregivers needed to rearrange financial, familial and professional aspects of their lives and 


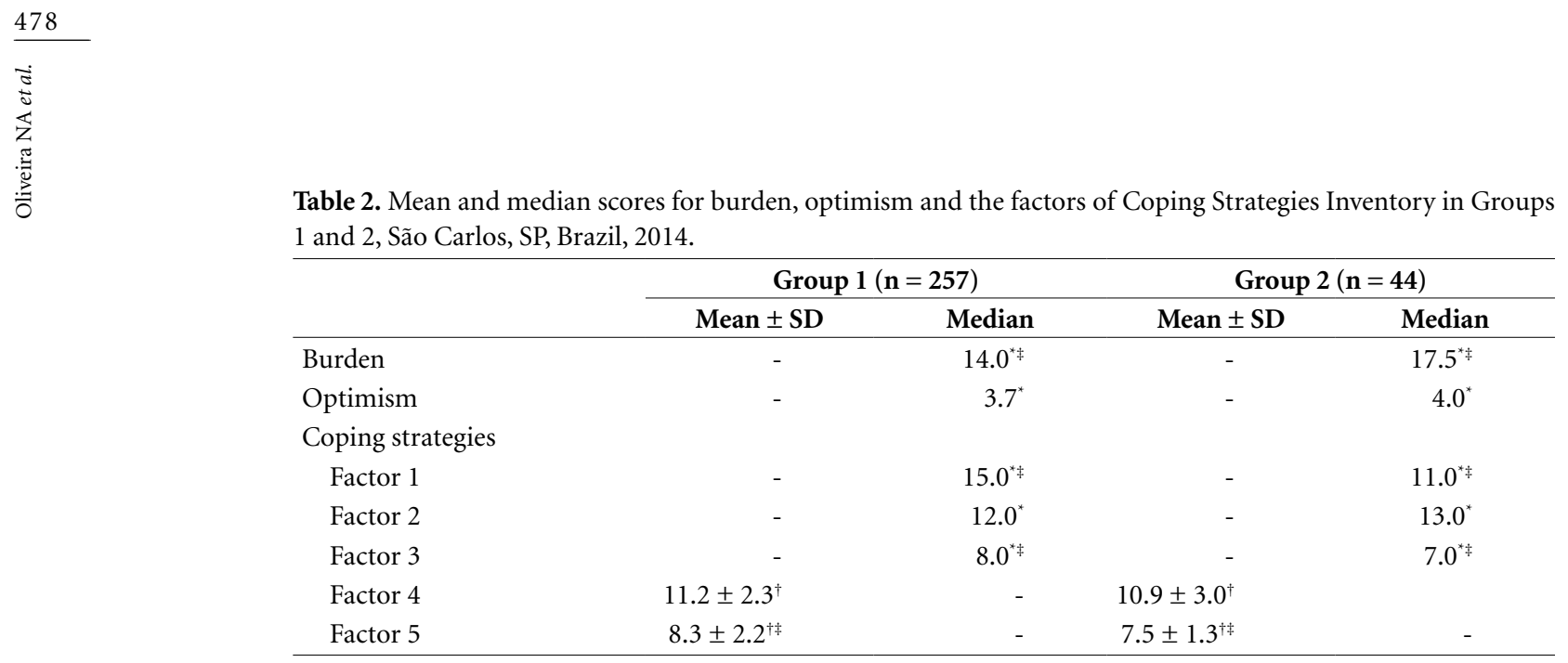

“Mann-Whitney U-test; 'Student's t-test; ${ }^{\ddagger} \mathrm{p} \leq 0.05$.

demonstrated concern with regard to the children's future due to their frail health. It should be noted that the children resided only with the grandparents in this study and the latter took on all care responsibilities, leading to an increase in burden $^{32}$. In contrast, the authors of a study evaluating the relationship between social support for elderly individuals with cognitive impairment and the presence/absence of children in the home found a higher degree of social support among the participants who resided with children ${ }^{33}$. Moreover, the authors of a two-year study conducted in Latin America involving 2000 elderly individuals aged 66 to 68 years found that grandparents who took care of their grandchildren for more than four hours per week had higher levels of satisfaction with life and a lower risk of developing depression ${ }^{34}$.

The young age of the children who resided with elderly caregivers in the present study may be an indication of their greater dependence with regard to daily activities, resulting in a greater burden for the caregiver in terms of workload and the time required for the caregiver to adapt to the situation. In Europe, care for grandchildren is considered a form of intergenerational solidarity and researchers stress the importance of programs directed at childcare to achieve a balance between formal care and that offered by grandparents in order to diminish the burden ${ }^{4}$.

The field of positive psychology stresses coping strategies and optimism as potential sources of stimulation to reduce the negative effects of excessive burden on physical, cognitive and psychological health ${ }^{35}$. Coping strategies assist caregivers in adapting to a given situation and are therefore considered a protective factor ${ }^{36}$. In the present investigation, elderly caregivers who did not reside with children reported greater use of coping strategies focused on emotion and religion.

The authors of a study involving adult caregivers of elderly individuals with a high degree of physical and cognitive dependence analyzed the social skills and coping strategies employed by the caregivers and also found a focus on emotion and religion. The use of such strategies is particularly important to caregivers by serving as a method of adaptation and assistance, since dependent elderly individuals often have physical and cognitive limitations stemming from chronic diseases for which the condition of dependence is irreversible ${ }^{37}$. The authors of a randomized study propose an intervention directed at the development of coping strategies and a reduction in the burden of caregivers of elderly individuals with dementia. The results of the study demonstrate that caregivers who participated in the intervention developed coping strategies focused on the problem and social support, which were effective at diminishing the level of burden ${ }^{36}$.

The differences between the two groups in the present investigation are important and offer direction for further studies that seek to explore coping strategies for care in the intergenerational context. The presence of a child in the home can be an incentive to seek and employ coping strategies as a tool for minimizing the effects of excessive burden regarding care to elderly individuals as well as improving quality of life and stimulating the positive aspects of intergenerational care, as children can be a source of support for elderly individuals in the future.

Optimism among the elderly caregivers was high in the present sample, with no significant difference between the two groups. This is an 
important aspect for health professionals in primary care to consider with regard to proposing interventions directed at the positive aspects of caregivers in order to help such individuals deal with the demands of care better. Data from a study that analyzed the relationship between level of optimism and stress in elderly caregivers of the elderly in an intergenerational context showed that optimism was an important variable for stress reduction in this context ${ }^{38}$. In another research with caregivers of elderly people with dementia researchers have identified that optimism is an important mediator variable to minimize feelings of anger and increase vitality ${ }^{39}$.

The present study has limitations that should be considered. The cross-sectional design does not allow the determination of the effect of time on the variables in the two situations analyzed. In this investigation, variables that could exert a positive or negative influence on care were evaluated, with the determination of which were found in the context of care with and without the presence of children in the home. However, other aspects, such as social support, family function and assistance with regard to caring for both children and elderly individuals, could minimize the negative impacts imposed by care giving and should be explored in future studies.

These findings offer important information for the development of interventions focused on minimizing the negative effects of care giving and the development of strategies to cope with this situation better. Special consideration should be given to families with the presence of children who are in the formative phase and who can also offer important social support to elderly caregivers. Moreover, children in this context can become a source of care for these individuals in the future.

\section{Conclusion}

In this study, a higher level of burden was identified in elderly caregivers who lived with children. For the optimism variable, no significant differences were found between groups. Regarding coping strategies, elderly caregivers who did not live with children present greater use of strategies centered on emotion and religion. The differences found between the two groups are important to increase knowledge about elderly caregivers and intergenerational coexistence, in addition they may direct other studies that seek to explore coping strategies for family care in different contexts. In the practical field, these results are relevant for primary care professionals because they can deepen the understanding about families with elderly caregivers and develop techniques to promote coping strategies in intergenerational or unidentifiable contexts that seek to minimize the negative effects of care overload and promote caregivers' health, and encourage intergenerational coexistence in the family environment as an important care resource. 


\section{Collaborations}

NA Oliveira, BM Luchesi, K Inouye and SCI Pavarini participated in the planning, conception and writing of the work. NA Oliveira, ÉN Souza and BM Luchesi participated in data collection and writing of the work. NA Oliveira and TS Alexandre participated in the analysis, interpretation of data and writing of the work.

\section{Acknowledgments}

The authors are grateful to all participants in the study. This study received funding from the following Brazilian fostering agencies: National Council for the Evaluation and Improvement of Higher Education Personnel (CAPES) in the form of a Master' grant and the State of São Paulo Assistance to Research Foundation (FAPESP).

\section{References}

1. Pinquart M, Sorensen S. Spouses, Adult Children, and Children-in-Law as Caregivers of Older Adults: A Meta-Analytic Comparison. Psychol Aging 2011; 26(1):1-14.

2. Ramos AC. The Grandparents in Children's Literature: gerontological and educational perspectives. Educ Real 2015; 40(1):191-225.

3. Musil CM, Gordon NL, Warner CB, Zauszniewski JA, Standing T, Way K. Grandmothers and caregiving to grandchildren: Continuity, change, and outcomes over 24 months. Gerontologist 2010; 51(1):86-100.

4. Igel C, Szydlik M. Grandchild care and welfare state arrangements in Europe. J Eur Soc Policy 2011; 21(3):210-224.

5. Ku LJE, Stearns SC, Van Houtven CH, Lee SY, Dilworth-Anderson P, Konrad TR. Impact of caring for grandchildren on the health of grandparents in Taiwan. J Gerontol B Psychol Sci Soc Sci 2013; 68(6):10091021.

6. Rose LE, Mallinson RK, Gerson D. Mastery, burden, and areas of concern among family caregivers of mentally ill persons. Arch Psychiatr Nurs 2006; 20(1):4151.

7. Silva DM, Vilela ABA, Nery AA, Duarte ACS, Alves MR, Meira SS. Dynamics of intergenerational family relationships from the viewpoint of elderly residents in the city of Jequié (Bahia), Brazil. Cien Saude Colet 2015; 20(7):2183-2191.

8. Lazarus RS. Hope: An emotion and a vital coping resource against despair. Social Research 1999; 66(2):653-678.

9. Antoniazzi AS, Dell'Aglio DD, Bandeira DR. O conceito de coping: uma revisão teórica. Estud Psicol 1998; 3(2):273-294.

10. Simonetti JP, Ferreira JC. Estratégias de coping desenvolvidas por cuidadores de idosos portadores de doença crônica. Rev Escol Enferm USP 2008; 2(1):19-25.

11. Charles ST. Strength and Vulnerability Integration: A Model of Emotional Well Being Across Adulthood. Psychol Bull 2010; 136(6):1068-1091.

12. Benight CC, Bandura A. Social cognitive theory of posttraumatic recovery: The role of perceived self-efficacy. Behav Res Ther 2004; 42(10):1129-1148.

13. Fortes-Burgos ACG, Neri AL, Cupertino APFB. Stressful Events, Coping Strategies, Self-Efficacy and Depressive Symptoms Among the Elderly Residing in the Community. Psicol Reflex Crit 2008; 21(1):74-82.

14. Alloy LB, Abramson LY, Whitehouse WG, Hogan ME, Panzarella C, Rose DT. Prospective incidence of first onsets and recurrences of depression in individuals at high and low cognitive risk for depression. J Abnorm Psychol 2008; 115(1):145-156.

15. Carver CS, Scheier MF, Segerstrom SC. Optimism. Clin Psychol Rev 2010; 30(7):879-889.

16. Blackwell SE, Rius-Ottenheim N, Schulte-van Maaren YW, Carlier IV, Middelkoop VD, Zitman FG, Spinhovenc P, Holmesa EA, Giltay EJ. Optimism and mental imagery: a possible cognitive marker to promote well-being? Psychiatry Res 2013; 206(1):56-61. 
17. Vilhena E, Pais-Ribeiro J, Silva I, Pedro L, Meneses, RF, Cardoso H, Silva AM, Mendonça D. Psychosocial factors as predictors of quality of life in chronic portuguese patients. Health Qual Life Outcomes 2014; 12:3.

18. Ruiz JM, Matthews KA, Scheier MF, Schulz R. Does who you marry matter for your health? Influence of patients' and spouses' personality on their partners' psychological well-being following coronary artery bypass surgery. J Pers Soc Psychol 2006; 91(2):255-267.

19. Giltay EJ, Zitman FG, Kromhout D. Dispositional optimism and the risk of depressive symptoms during 15 years of follow-up: The Zutphen Elderly Study. J Affect Disord 2006; 9(1):45-52.

20. Steptoe A, Wright C, Kunz-Ebrecht SR, Iliffe S. Dispositional optimism and health behaviour in community-dwelling older people: Associations with healthy ageing. Br J Health Psychol 2006; 11(1):71-84.

21. Katz S, Ford AB, Moskowitz RW, Jackson BA, Jaffe MW. Studies of illness in the aged: the index of ADL: a standardized measure of biological and psychosocial function. JAMA 1963; 185(12):914-919.

22. Lawton MP, Brody EM. Assessment of folder people: self-maintaining and instrumental activities of daily living. Gerontologist 1969; 9(3):179-186.

23. Luchesi BM, Souza ÉN, Gratão ACM, Gomes GAO, Inouye K, Silva AT, Marques S, Pavarini SCI. The evaluation of perceived stress and associated factors in elderly caregivers. Arch Gerontol Geriatr 2016; 67:7-13.

24. Scazufca M. Brazilian version of the Burden Interview scale for the assessment of burden of care in carers of people with mental illnesses. Rev Bras Psiquiatria 2002; 24(1):12-17.

25. Pinto C, Pais-Ribeiro JL. Construção de uma escala de avaliação da espiritualidade em contextos de saúde. Arq Med 2007; 21(2):47-53.

26. Chaves EDCL, Carvalho ECD, Dantas RAS, Terra FDS, Nogueira DDP, Souza LD. Validation of Pinto and Pais-Ribeiro's spirituality scale in patients with chronic renal insufficiency in hemodyalisis. $J$ Nurs UFPE Online 2010; 4(2):715-721.

27. Aldwin CM, Sutton KJ, Lachman M. The development of coping resources in adulthood. J Pers 1996; 64(4):837-871.

28. Chen MC, Chen KM, Chu TP. Caregiver burden, health status, and learned resourcefulness of older caregivers. West J Nurs Res 2015; 37(6):767-780.

29. Gratão ACM, Silva TLF, Figueiredo LC, Rosset I, Freitas CP, Rodrigues RAP. Dependência funcional de idosos e a sobrecarga do cuidador. Rev Escol Enferm USP 2013; 47(1):137-144.

30. Nardi EDFR, Sawada NO, Santos JLF. The association between the functional incapacity of the older adult and the family caregiver's burden. Rev Latino Am Enfermagem 2013; 21(5):1096-1103.

31. Brodaty $\mathrm{H}$, Woodward M, Boundy K, Ames D, Balshaw R, PRIME Study Group. Prevalence and predictors of burden in caregivers of people with dementia. Am J Geriatr Psychiatry 2014; 22(8):756-765.
32. Mainetti AC, Wanderbroocke ACNDS. Avós que assumem a criação de netos. Pensando Fam 2013; 17(1):87-98.

33. Luchesi BM, Brito TRP, Costa RS, Pavarini SCI. Suporte social e contato intergeracional: estudando idosos com alterações cognitivas. Rev Eletr Enferm 2015; 17(3):1-8.

34. Grundy EM, Albala C, Allen E, Dangour AD, Elbourne D, Uauy R. Grandparenting and psychosocial health among older Chileans: A longitudinal analysis. Aging Ment Health 2012; 16(8):1047-1057.

35. Cassidy T, McLaughlin M, Giles M. Applying a resource model of stress to the cancer caregiver experience. Clinical Nursing Studies 2015; 3(2):59-66.

36. Chen HM, Huang MF, Yeh YC, Huang WH, Chen CS. Effectiveness of coping strategies intervention on caregiver burden among caregivers of elderly patients with dementia. Psychogeriatrics 2015; 15(1):20-25.

37. Pinto FNFR, Barham EJ. Habilidades sociais e estratégias de enfrentamento de estresse: relação com indicadores de bem-estar psicológico em cuidadores de idosos de alta dependência. Rev Bras Geriatr Gerontol 2014; 17(3):525-39.

38. Oliveira NA, Souza EN, Luchesi BM, Inouye K, Pavarini SCI. Stress and optimism of elderlies who are caregivers for elderlies and live with children. Rev Bras Enferm 2017; 70(4):697-703.

39. López J, Romero-Moreno R, Márquez González M, Losada M. Anger and Health in Dementia Caregivers: Exploring the Mediation Effect of Optimism. Stress Health 2015; 31(2):158-165.

Article submitted 30/01/2018

Approved 24/05/2018

Final version submitted 26/05/2018 
